\title{
Assessment of Economic Inequality of the Regions of Siberia (Based on the Dairy Industry)
}

\author{
Chernyakov M.K. ${ }^{1, *}$ Chernyakova M. ${ }^{2}$ Prikhodko E. ${ }^{1}$
}

\author{
${ }^{1}$ Audit, Accounting and Finance Department, Novosibirsk State Technical University, 630073, Russia \\ ${ }^{2}$ Management Department, RANEPA Siberian Institute of Management, 630102, Russia \\ *Corresponding author. Email: mkacadem@mail.ru
}

\begin{abstract}
In recent years, issues of assessing the impact of government programs, both on overcoming the socioeconomic differentiation of regions and on the development of individual sectors of the national economy, have attracted steady interest. Research is carried out both by domestic and foreign scholars. However, few studies are devoted to the search and development of a systematic approach to assess the effectiveness of the government regulation of a particular industry. The dairy industry makes a significant contribution to the formation of the food, and, as a consequence, national security. It is not known how scholars, assessing the effectiveness of government programs, attribute their influence to the development of the region's economy, as well as its dairy industry. The purpose of our work is to identify the relationship between the system of the government regulation of the dairy industry and its economic efficiency on the example of Novosibirsk Region based on the innovative diversification approach, which includes a combination of innovative, diversification, and synergetic approaches. In order to build mathematical models of the impact of government programs and policies, we have used the methods of correlation and regression analysis. The results of the study indicate that there is a functional relationship between the parameters that shape the content of government programs and policies and the efficiency of the dairy industry development. The calculations made it possible to take into account the interactions between parameters that do not have a direct linear relationship. It seems that the developed methodology for assessing the impact of government programs on the dairy industry functioning will allow for adjustments to regional policies in the field of the dairy industry development and rational use of budget funds at various levels. The scientific novelty of the study lies in the development of a unified methodology for assessing the impact of government regulation on the dairy industry effectiveness.
\end{abstract}

Keywords: dairy industry, food security, government programs, policies, correlation and regression analysis,

modelling, innovative diversification approach

\section{INTRODUCTION}

The problems of inequality are widespread in the global economy, multifaceted, and, to some extent, objectively and subjectively inevitable. Despite this, we believe that if the intensification of socioeconomic inequality of territories is not properly monitored and evaluated, and necessary measures are not taken to combat it and appropriate measures are taken, it can lead to a variety of political, economic, and social crises and probably disasters. That is why there has been growing interest in food security in general and the role of the State in this process in particular around the world in recent years. For transcontinental Russia, which occupies 1/9 of the Earth's land, issues of ensuring national security, including a food one, while ensuring the sustainable and balanced spatial development, taking into account economic, social, and environmental interests, both at the national and territorial levels, remain one of the priority tasks of the government policy over a long period of time. One of the key areas of food security is providing the population with dairy products [1]. In this regard, it is necessary to ensure sustainable effective development and operation of the industry. The dairy industry, being an integral part of the food industry, is in every State, but its state and level of development in different countries have significant differences. The leaders of the dairy industry are economically developed countries, such as Europe, USA, India, China, New Zealand, and Australia. Moreover, the United States is the main producer of milk, they account for $25 \%$ of the total production [2]. Russia is one of the ten largest producers and it takes the sixth place; its share in the total milk production is about $8 \%$.

The state and development of the dairy industry are significantly influenced by the country's existing system of the government regulation of this sector of the economy. In turn, high demands are placed on the public administration system, one of which is its effectiveness. In the scientific literature, a lot of research is associated with the assessment of government programs and policies [2-6]. However, few authors analyze the relationship between government 
programs and the development efficiency of industries for which these programs are being formed [4]. In our opinion, the study of the influence of the government policy on the state and development of the dairy industry is of undoubted scientific interest. In our study, we would like to summarize the accumulated experience and to propose a unified approach to assessing the impact of the government regulation on the efficiency of the dairy industry based on the Siberian Federal District.

The results of our and similar studies will be of interest to specialists involved in the development and implementation of government programs and policies, heads of dairy enterprises, as well as scholars conducting research in this and related areas.

\section{LITERATURE REVIEW}

The configuration of the socioeconomic space of Russia is characterized by heterogeneity and imbalance, which inhibits the movement towards sustainable development, leads to increased interregional contrasts. It is worth noting that the problem of inequality in the economic development of the territories is of interest to scholars and it has been studied by them for more than two hundred years. As far back as the $19^{\text {th }}$ century, the rationale for the application of differentiation methods to calculations of the appropriateness of production location [1] takes place, and the theory of production location by W. Launhardt, A. Weber, J. Peak, V. Rocher, T. Palander, A. Lesh, B. G. Olin, W. Christaller, M. Porter, M. Fujita, P. R. Krugman [2-6].

Among the studies in which the theory of economic inequality was developed, one cannot fail to note the work of the French economist F. Perroux, who developed the concept of "growth poles" (poles de croissance) [7-8]. According to this concept, the economic growth does not occur evenly, but manifests itself in the centers of the economic space ("growth poles"), but then it can spread to different territories with different intensities. F. Perroux made an important methodological conclusion that inequality should be considered as a fundamental principle of economic development and that it follows from differences in the sizes of production and capital, from different degrees of awareness of counterparties, their belonging to different areas of the economy. The ideas of F. Perroux were developed in the works of J. Budville, who singled out the types of economic spaces and proposed a hierarchy of growth centers, H. Richardson, who pointed out the role of agglomerations in the formation of growth poles, and H.R. Lasuen, who described a number of important features of growth poles [4, 9-11].

A significant role in research revealing the mechanisms of spatial development (including its unevenness) is played by the work by J. Friedmann, the founder of the centerperiphery theory's,-_Regional Development Policy [12]. According to the scholar, one of the main reasons for the uneven development is scientific and technological progress, which leads to the fact that centers at any spatial level attract resources from the periphery, thereby forming not only the possibility of innovative development, but also imbalances between territories. Regional science has proved that spatial inequality arises as an objective consequence of the concentration of competitive advantages in some territories and their absence or deficit in others. The effect of the concentration of economic activity in business-friendly areas was revealed by G. Myrdal in the middle of the $20^{\text {th }}$ century [13]. A major role in understanding the laws of space development was played by the center-peripheral theory (theory of polarized development) developed by J. Friedmann [12].

P. Krugman systematized the competitive advantages of territories, distinguishing two groups of factors [6]. Factors of the "first nature" include the availability of natural resources (mineral, land, etc.) that are demanded by the market, as well as the geographical location, including the position on the paths of global trade, which reduces transport costs and facilitates the translation of innovations. These advantages are objective and exist regardless of the activities of people. Factors of the "second nature" include the advantages created by the activities of human and society: the agglomeration effect (high population density in cities, which gives economies of scale); human capital (education, health, labor motivation, mobility, and adaptability of the population); institutions that contribute to improving the business climate, population mobility, the spread of innovation, etc.

In the long run, it is precisely the factors of the "second nature" that contribute to slowing the growth of economic inequality in the regions and the emergence of new growth zones. At the same time, economic growth exacerbates regional inequality; there is no smoothing of regional differences. The World Bank Report for 2009 has shown that in the developed countries of Europe and the USA, the peak of regional inequality growth occurred at the end of the $19^{\text {th }}$ - first half of the $20^{\text {th }}$ century, that is, during the period of industrial development, and towards the end of the $20^{\text {th }}$ century inequality growth has slowed [14].

As the studies of F. Martin show, the divergence and convergence trends for countries and regions do not coincide [15]. Thus, the less developed countries of Western Europe, which became part of the European Union in the 1970s and 1980s, were able to reduce the lag in the level of development, measured by per capita GDP, from the more developed countries - old EU members, but the cost of success was the growth of regional inequality within the majority of less developed countries. The dynamics of inequality for the period from 1990 to 2000 was measured using the standard deviation of per capita GDP indicators at the level of EU countries and at the level of NUTS 21 regions. Other studies also show that from the mid-1980s to the end of the 1990s, differences in the level of development between EU member countries decreased by $25 \%$, and imbalances in the development of their regions increased by $10 \%$ [16]. Different trends for countries and their regions are understandable. Inequality within the country is growing because business invests in those regions that have competitive advantages in order to reduce costs.

Since the second half of the $20^{\text {th }}$ century, regional science has developed a stable consensus in understanding spatial 
development: it cannot be uniform. This is due to two basic concepts that have stood the test of time. Firstly, it is the center-peripheral theory (model) of spatial development created by J. Friedmann: centers of different levels, always drawing resources (human, financial, natural) from their periphery. It is the concentration of resources that creates opportunities for innovative changes of the centers themselves, and then these innovations are transmitted to the periphery with a lag in time, depending on the size of the barriers to the movement of innovation [12]. Secondly, these are studies of the processes of spatial concentration of the economy, including in the framework of the "new economic geography" of the middle and the end of the $20^{\text {th }}$ century, for which P. Krugman received the Nobel Prize in 2008 [6].

Russian studies of factors and trends in regional inequality are still few. It is impossible not to note the development of M.K. Bandman and the scientific school under his leadership in Novosibirsk [2], to the ideas of which we are returning today at a new level, as well as the founders of the Russian school of spatial interdisciplinary research of A.G. Granberg, under whose leadership development programs were designed for the Ural, Siberia, and the Far East, receiving new understanding and continuation today, and also P.Ya. Baklanov [17-19]. Research is being conducted on the Council for the Study of Productive Forces under the Ministry of Economic Development in the field of methodological and methodical support for forecasting and analytical studies of the socioeconomic development of the Russian Federation and its regions; the formation of scientific and methodological support of government strategic planning and regulation of the spatial development of Russia and the socioeconomic development of its regions. Institutions of the Russian Academy of Sciences are also involved in territorial development issues. In order to increase the effective use of economic resources, taking into account the objective unevenness of the spatial distribution of effects from the use of production factors in the territory of the Russian Federation, The Spatial Development Strategy of the Russian Federation for the Period up to 2025 [20] was adopted by the Government in 2019 and The Plan for the Implementation of the Spatial Development Strategy of the Russian Federation for the Period up to 2025 was approved [21].

The methodology for assessing the inequality of territories is gradually improving, although the most typical way of measuring is to compare the values of the polar Russian regions or their groups, based on which conclusions about the extremely strong and growing regional differentiation are being drawn. Quantitative studies using modern techniques appeared only in the 2000s. Two works of the Institute for the Economy in Transition [22] can be distinguished, in which two interconnected concepts of convergence are tested using spatial econometrics based on the regional inequality in Russia. (Hypotheses about the presence of $\beta$-convergence, which implies the accelerated development of poorer regions, which should lead to an equalization of the level of economic development, and $\sigma$ convergence, in which there is a reduction in the interregional spread of per capita GRP, have been tested.
For calculations, we used data on the per capita GRP for 1996-2004, adjusted for the cost of living in the regions. The hypothesis of $\sigma$-convergence has not been confirmed, fluctuations in the coefficient of variation turned out to be statistically insignificant, which means that there is no obvious tendency to decrease or increase regional inequality. The same results have been obtained for $\beta$ convergence in general, although the calculations of conditional $\beta$-convergence (the influence of the neighborhood) show that, ceteris paribus, there is a positive effect of more developed regions on the development dynamics of neighboring less developed regions).

\section{RESEARCH METHODOLOGY}

\subsection{Morphological analysis}

Morphological analysis was chosen as a preliminary research method for assessing the socioeconomic inequality of the regions, which is an effective methodological approach - a way of seeing and a generalized attitude to reality. F. Zwicky [23] proposed to generalize and to systematize the concept of morphological research and to include in it not only studying the forms of geometric, geological, biological, and generally material structures, but also studying more abstract structural relationships between phenomena, concepts, and ideas, whatever their character. This method is based on the construction of a matrix in which all the main parameters of the object are listed along the vertical axis and the largest possible number of options for their implementation are indicated along the horizontal one. The combination of the obtained options for the object elements leads to the generation of creative ideas and solutions [24].

\subsection{Input data}

In order to conduct a morphological analysis, it is necessary to determine the possible parameters that characterize the dairy industry and approaches that allow formalizing the processes taking place in it. As parameters of the formalized model proposed in [25], using ranking methods and economic interpretation, 7 classification groups, including 15 key industry indicators, structured in Figure 3, covering all areas of the Russian dairy industry, have been included. The designations proposed for the analysis of the main indicators of the dairy industry, shown in Figure 1, are available in open sources. The authors assigned their designations for the formal description and manipulation in mathematical models. As is accepted in most studies, indicators have been designated by the Latin symbol $\mathrm{X}$ and a digit defining the number in the order located in Figure 1. As the second parameter of the morphological model, we should consider the regions in the order defined in the analysis of the available resources of milk and dairy products. As is customary in most studies, indicators have 
been designated by the Latin symbol $\mathrm{Y}$ and a number defining the number in the order located in the results of assessments of resource potential.

\begin{tabular}{|c|c|}
\hline Production, thousand tons & $\begin{array}{l}\cdot \mathrm{X} 1 \text { - milk in farms of all categories } \\
\cdot \mathrm{X} 2 \text { - trade milk }\end{array}$ \\
\hline $\begin{array}{l}\text { Cow population at the end } \\
\text { of the year, thousands of heads }\end{array}$ & $\begin{array}{l}\cdot \mathrm{X} 3 \text { - in farms of all categories at the end of the year } \\
\cdot \mathrm{X} 4 \text { - in agricultural organizations (ACOs), peasant farm } \\
\text { enterprises (PFEs), personal subsidiary plots (PSPs) }\end{array}$ \\
\hline Share of brood cows, $\%$ & $\begin{array}{l}\cdot \mathrm{X} 5 \text { - in ACOs, PFEs, PSPs } \\
\cdot \mathrm{X} 6 \text { - milk and combined directions of productivity }\end{array}$ \\
\hline $\begin{array}{l}\text { Milk producing ability of cows, } \\
\qquad \mathrm{kg} \text { year }\end{array}$ & $\begin{array}{l}\cdot \mathrm{X} 7 \text { - in farms of all categories } \\
\cdot \mathrm{X} 8 \text { - in ACOs } \\
\cdot \mathrm{X} 9 \text { - in PFEs } \\
\text {-X10 - in PSPs } \\
\text { - X11-brood cows }\end{array}$ \\
\hline $\begin{array}{l}\text { Milk and dairy products per } \\
\text { capita, kg/year }\end{array}$ & $\begin{array}{l}\cdot \mathrm{X} 12 \text { - production } \\
\text {-X13 - consumption }\end{array}$ \\
\hline Milk processing, $t$ & -X14 - dairy production in terms of milk \\
\hline Amount of funds, million rubles & -X15 - government support for the dairy industry \\
\hline
\end{tabular}

Figure 1 Classification of indicators characterizing the dairy industry [15-16]

\section{RESULTS OF EXPERIMENTAL RESEARCH}

An analysis of the state of the dairy industry in the Siberian Federal District [26] has shown that both milk production and consumption are at a very high level for the Russian Federation. The level of self-sufficiency of the population with milk and dairy products is one of the highest in Russia. In 2017, the share of own production in the Siberian Federal District was $69 \%$, while import from other regions and imports-28\%. Figure 2 shows an analysis of the resources of milk and dairy products for 2017 by the regions in the Siberian Federal District. Altai Krai has the largest resources, and the Republics of Khakassia and Tuva have more than an order of magnitude less resources.

Therefore, based on the available resources of the Republic of Khakassia and Tuva, it can be attributed to the depressed regions, to which it is necessary to apply anti-crisis measures of the government regulation. However, it is not always objective to draw a conclusion on one, albeit complex, indicator; hence, in order to clarify the level of regional depression, it is necessary to use morphological analysis to study a larger number of parameters of the dairy industry.

Based on the analysis, a morphological matrix has been formed (Table 1). 
Table 1 Morphological matrix of ranking the regions of the Siberian Federal District by indicators of the dairy industry

\begin{tabular}{|c|c|c|c|c|c|c|c|c|c|c|}
\hline Designation & $\mathrm{Y} 1$ & $\mathrm{Y} 2$ & Y3 & Y4 & $\mathrm{Y} 5$ & Y6 & Y7 & Y8 & Y9 & Y10 \\
\hline $\mathrm{X} 1$ & 1 & 4 & 3 & 2 & 6 & 5 & 8 & 7 & 9 & 10 \\
\hline $\mathrm{X} 2$ & 1 & 3 & 2 & 4 & 6 & 5 & 7 & 9 & 8 & 10 \\
\hline $\mathrm{X} 3$ & 1 & 4 & 2 & 3 & 8 & 6 & 10 & 7 & 5 & 9 \\
\hline $\mathrm{X} 4$ & 1 & 3 & 2 & 4 & 8 & 6 & 9 & 7 & 5 & 10 \\
\hline $\mathrm{X} 5$ & 7 & 4 & 5 & 1 & 6 & 3 & 2 & 8 & 9 & 10 \\
\hline X6 & 7 & 4 & 5 & 1 & 6 & 2 & 3 & 8 & 9 & 10 \\
\hline $\mathrm{X7}$ & 3 & 6 & 5 & 2 & 4 & 7 & 1 & 8 & 9 & 10 \\
\hline $\mathrm{X} 8$ & 3 & 6 & 5 & 2 & 4 & 7 & 1 & 8 & 9 & 10 \\
\hline X9 & 3 & 6 & 5 & 2 & 4 & 7 & 1 & 8 & 9 & 10 \\
\hline $\mathrm{X} 10$ & 3 & 6 & 5 & 2 & 4 & 7 & 1 & 8 & 9 & 10 \\
\hline $\mathrm{X} 11$ & 3 & 6 & 5 & 2 & 4 & 7 & 1 & 8 & 9 & 10 \\
\hline $\mathrm{X} 12$ & 1 & 5 & 2 & 7 & 8 & 9 & 4 & 6 & 3 & 10 \\
\hline $\mathrm{X} 13$ & 1 & 5 & 2 & 7 & 8 & 9 & 4 & 6 & 3 & 10 \\
\hline $\mathrm{X} 14$ & 1 & 2 & 5 & 3 & 4 & 6 & 8 & 7 & 9 & 10 \\
\hline $\mathrm{X} 15$ & 1 & 3 & 2 & 4 & 5 & 6 & 7 & 8 & 9 & 10 \\
\hline Total points & 37 & 67 & 55 & 46 & 85 & 92 & 67 & 113 & 114 & 149 \\
\hline Region rating & 1 & 4 & 3 & 2 & 6 & 7 & 5 & 8 & 9 & 10 \\
\hline $\begin{array}{l}\text { The state of the } \\
\text { regions }\end{array}$ & \multicolumn{2}{|c|}{ promising } & \multicolumn{2}{|c|}{ positive } & \multicolumn{2}{|c|}{ stable } & \multicolumn{2}{|c|}{ pre-depressive } & \multicolumn{2}{|c|}{ depressive } \\
\hline Point interval & \multicolumn{2}{|c|}{ Less than 30} & \multicolumn{2}{|c|}{ From 31 to 60} & \multicolumn{2}{|c|}{ From 61 to 90} & \multicolumn{2}{|c|}{ From 91 to 120} & \multicolumn{2}{|c|}{ More than 121} \\
\hline $\begin{array}{l}\text { The number of } \\
\text { regions in the } \\
\text { interval }\end{array}$ & & & \multicolumn{2}{|c|}{3} & \multicolumn{2}{|c|}{3} & \multicolumn{2}{|c|}{3} & \multicolumn{2}{|c|}{1} \\
\hline \multirow{3}{*}{ Regions } & & & \multicolumn{2}{|c|}{ Y1.Altai Krai } & \multicolumn{2}{|c|}{ Y2.Omsk Region } & \multicolumn{2}{|c|}{ Y6.Irkutsk Region } & \multicolumn{2}{|c|}{ Y10.Republic of Tuva } \\
\hline & & & \multicolumn{2}{|c|}{ Y4.Krasnoyarsk Krai } & \multicolumn{2}{|c|}{ Y7.Tomsk Region } & \multicolumn{2}{|c|}{$\begin{array}{l}\text { Y8.Republics of } \\
\text { Khakassia }\end{array}$} & & \\
\hline & & & \multicolumn{2}{|c|}{$\begin{array}{c}\text { Y3.Novosibirsk } \\
\text { Region }\end{array}$} & \multicolumn{2}{|c|}{$\begin{array}{l}\text { Y5.Kemerovo } \\
\text { Region }\end{array}$} & \multicolumn{2}{|c|}{ Y9.Altai Republic } & & \\
\hline
\end{tabular}




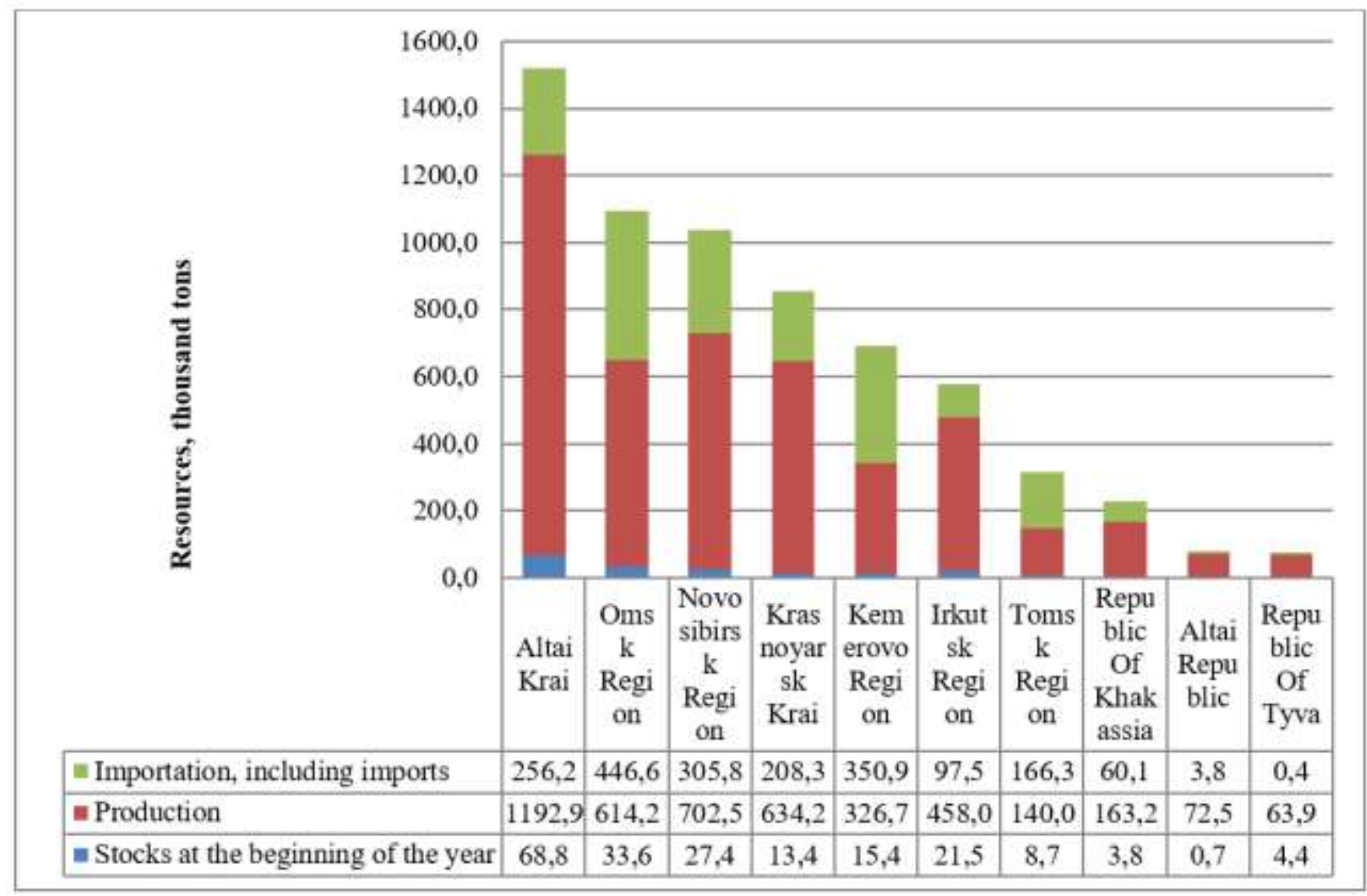

Figure 2 Dairy resources by regions of Siberia [27]

\section{RESULTS AND DISCUSSION}

As a result of the morphological analysis, 5 clusters of the state of the regions have been formed. Not a single region fell into a promising cluster, but three regions each entered into a positive, stable, and pre-depressive cluster, and only one region has been classified as depressed-this is the Republic of Tuva.

It should be noted that there are significant discrepancies in the results of assessments of the resource potential (Fig. 2) [26] and morphological analysis. The common in their assessments was the unconditional first place in Altai Krai, the third place of Novosibirsk Region, and the last three places of the Republics of Khakassia, Altai, and Tuva.

It is established that the form of administrative management also influences the rating of regions. The Krais occupy the upper level in the hierarchy, the regions are intermediate ones, and the Republics are the lowest one. In this paper, the influence of administrative forms on the rating of the region has not been investigated and it will be the subject of further research.

\section{CONCLUSION}

The paper has studied the role of the State influence through the implementation of programs on the state and development of the dairy industry.

So, the analysis of the state of the dairy industry in the Siberian Federal District has shown that both the production and consumption of milk are at a very high level for the Russian Federation. The level of self-sufficiency of the population with milk and dairy products is also one of the highest in Russia.

However, these indicators vary greatly depending on the particular constituent entity. This is due, inter alia, to the existing policy of regional authorities in the field of production and sale of agricultural products. In many regions, the activities are being implemented that are consistent with the Government Program for the Development of Agriculture for 2013-2020, which increases the efficiency of regulation of agricultural products, raw materials, and food markets.

An assessment of the situation in the dairy market of the Siberian Federal District gives a general idea of current trends in the production and consumption of dairy products. In order to form a holistic view of the situation of the regions in the market, it is necessary to further evaluate its local environment. Close attention should be given to 
[10] Lasuen, H.R. Urbanization and Economic Development: Temporary Interactions between Geographic and Industry Clusters [Text] / H.R. Lasuen // Spatial Economics. - 2010. - No. 1. - Pp. 68-101.

[11] Richardson, H. W. Regional Growth Theory [Text] / H. W. Richardson. - London: MacMillan, 1973. -P. 272

support of Novosibirsk State Technical University (project No. 19-12).

\section{REFERENCES}

[1] Thunen, I. G. Isolated State / I. G Thunen; trans. by Ye. A. Thorneus; edited and with a foreword by Prof. A. A. Rybnikov. - M.: Economic Life, 1926. $326 \mathrm{pp}$.

[3] Blaug, M. R. 100 Great Economists before Keynes / M. R. Blaug, G. F. Wilhelm. - SPb. : Economicus, 2008 $-352 \mathrm{pp}$

[3] Blaug, M. R. Theory of Weber's Industrial Enterprises / M. R. Blaug // Economic Thought in Retrospect. - M. : Delo, 1994. - 720 pp.

[4] Granberg, A. G. Fundamentals of Regional Economics / A. G. Granberg - M. : HSE, 2000. - 495 pp. - P. 14.

[5] Olin, B. Interregional and International Trade / B. Olin ; edited by A. P. Kireev // Milestones of Economic Thought. Vol. 6. International Economics. M. : TEIS, 2006. - Pp. 174-187.

[6] Krugman, P. R. The Spatial Economy : Cities, Regions and International Trade / Krugman P.R. Masahisa Fujita, Anthony J.V. - The MIT Press, London, 1999. - 367 pp.

[7] Perroux, F. Note sur la ville consideree comme pole de developpement et comme foyer du progres [Text] / F. Perroux // Revue Tiers-Monde. - 1967. - Vol. 8. - No. 32. - Pp. 1147-1158;

[8] Perroux, F. Les investissements multinationaux et l'analyse des poles de developpement et des poles d'integration [Text] / F. Perroux // Revue TiersMonde. - 1968. - Vol. 9. - No. 34. - Pp. 239-265.

[9] Lasuen, H.R. Urbanization and Economic Development: Temporary Interactions between Geographic and Industry Clusters [Text] / H.R. Lasuen // Spatial Economics. - 2009. - No. 4. - Pp. 106-125.
[12] Friedmann, J. Regional Development Policy: A Case of Study Venezuela [Text] / J. Friedmann. - MIT Press, 1966, P.17.

[13] Myrdal G. Economic Theory and Underdeveloped Regions. London: Duckworth, 1957.

[14] World Development Report - 2009. Reshaping Economic Geography. World Bank, 2009.

[15] Martin P. The Geography of Inequalities in Europe // Swedish Economic Policy Review. 2005. № 12. Pp. 83- 108 .

[16] Duro J.A. Regional Income Inequalities in Europe: an Updated Measurement and Some Decomposition Results. Mimeo: CSIC, 2001.

[17] Baklanov, P.Ya. Representations of Territorial Socioeconomic Structures / P. Ya. Baklanov // Geosystems of the Russian Far East at the Turn of the $20^{\text {th }}-21^{\text {st }}$ centuries Vol. 3. Territorial Socioeconomic Structures. Vladivostok: Dalnauka. - 2012. - Pp. 11-35.

[18] Baklanov, P.Ya. Spatial Production Systems (Microstructural Level of Analysis and Management) / P. Ya. Baklanov - M. : Nauka, 1986. - 150 pp.

[19] Baklanov, P.Ya. Structuring the Territorial Socioeconomic Systems / P. Ya. Baklanov // Bulletin of Moscow University. "Series 5: Geography". - 2013. No. 6. - Pp. 3-8.

[20] The Spatial Development Strategy of the Russian Federation for the Period up to 2025 approved by the Order of the Government of the Russian Federation dated February 13, 2019, No. 207-r.

[21] The Plan for the Implementation of the Spatial Development Strategy of the Russian Federation for the Period up to 2025 approved by the Order of the Government of the Russian Federation dated December 27, 2019, No. 3227-r.

[22] Drobyshevsky S., Lugovoi O., Astafieva E. et al. Factors of Economic Growth in the Regions of the Russian Federation. M.: GIEP, 2005, Economic- 
Geographical and Institutional Aspects of Economic Growth in the Regions. M.: GIEP, 2007.

[23] Zwicky, F. Discovery, Invention, Research Through the Morphological Approach. Toronto: The Macmillan Company, 1969, 276 pp. https://www.amazon.com/Discovery-Invention-

Research-morphological-approach/dp/B0006BYL8U

[24] Markov, S. Morphological Analysis / Activating Creativity? 2018/

https://geniusrevive.com/en/morphological-analysis/

[25] Chernyakov, M.K.; Chernyakova, M.M. and Akberov, K.Ch. Innodiversification Model of the Digital Economy of the Agricultural Sector, Advances in Social Science, Education and Humanities Research, 2019, 240, DOI: $10.2991 /$ sicni-18.2019.114. https://www.atlantispress.com/proceedings/sicni-18/55911909

[26] Chernyakova, M. M. The Paradoxical Theory of Regulation in the AIC (Based on the Dairy Industry): a Monograph. - Novosibirsk: NSTU, 2019, 160 pp. https://www.elibrary.ru/item.asp?id=41342340

[27] Federal State Statistics Service. - [Electronic resource]. $\quad-\quad$ Access mode: http://www.gks.ru/wps/wcm/connect/rosstat_ main/rosstat/ru/statistics/publications/catalog/doc_1286 360627828 (last accessed date: September 9, 2019). 